\title{
Urban cartography in the morphogenetic analysis of urban spaces: the case of the Boavista axis in the city of Porto
}

\author{
Mário Gonçalves Fernandes ${ }^{\mathrm{a}}$, Rui Passos Mealha ${ }^{\mathrm{b}}$ \\ ${ }^{a}$ Faculdade de Letras da Universidade do Porto e CEGOT, mgfernan@letras.up.pt \\ ${ }^{b}$ Faculdade de Arquitectura da Universidade do Porto e CEAU, rmealha@gmail.com
}

\begin{abstract}
:
Starting from a morphogenetic study of the Boavista axis, in the city of Oporto, a comparative analysis of the characteristics of the urban cartographic documents used (about two dozen surveys/projects, dating from the late 18th century to the beginning of the 20th century) and emphasizes the use of ancient urban cartography as an important tool for knowledge and recognition of urban morphogenesis, such as a framework of current urban action.

Being one of the elements that are most evident in the urban network of Porto, the Boavista axis looks like the result of a single planning feature and he is also notable because it was built between the 18th and 20th centuries, corresponding to the political persistence of several generations of municipal power. Contrary to its form, its history is not linear and although considering the course of Rua da Boavista as the genesis conditioning the layout of the Avenida da Boavista, each (street and avenue) evokes distinct urban designs, based on different territorial and urban strategies.

The formation of the Boavista axis between 1784 and 1915/17 was more complex, but urban cartography allows identifying each of its structuring periods, either by identifying the physical elements that identify the phasing process, or by the intrinsic characteristics of the various documents cartographic.
\end{abstract}

Keywords: urban cartography, urban morphogenesis 


\section{The cartographic documents}

To support the development of studies of urban morphogenesis, in Portugal it is more frequent to find cartographic documents of great scale since the 18th century. From the eighteenth century, three phases can be distinguished, differentiated based on the characteristics of the documents in relation to the symbologies, to the elements of the map and the respective organization. Thus, the following phases can be identified:

- modern phase, which begins with Manoel de Azevedo Fortes, includes almost every eighteenth century and extends through the nineteenth century;

- contemporary phase, which includes much of the 19th century;

- transition phase, which contains the first republic (1910-1926) and runs until the thirties;

- Estado Novo phase (1933-1974), with its own specific technical and aesthetic characteristics.

As previously explained (Mario G. FERNANDES, coord., 2006), the rules and symbology used in largescale cartography are derived from the teachings contained in the first cartographic cartographic elements published in Portuguese, namely in the "The easiest and most accurate way of making the Geographical Maps" of 1722 and particularly in Chapters IX and X (denominated, respectively "The Use of the Instruments Most Needed to Engineers "and" The Design of Military Plans", of Book III, Volume I of $O$ Engenheiro Portuguez (The Portuguese Engineer), published in 1728 and authored by Manoel de Azevedo Fortes, Master Engineer of the kingdom.

In fact, in addressing issues related to drawing techniques, map elements, and the clarification of symbologies, those publications have become essential references that help to understand cartographic documents of the eighteenth and later centuries, both in military cartography and in elaborate cartography for civil purposes.

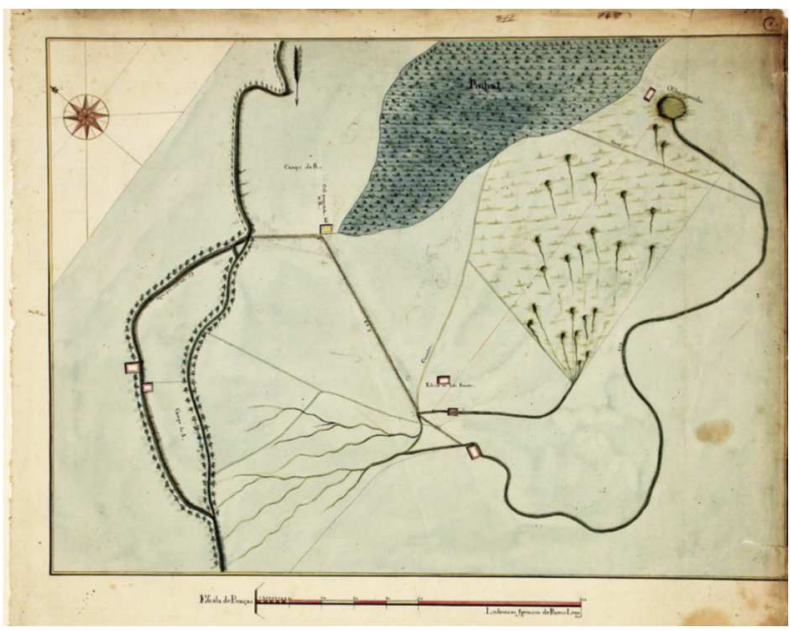

Figure 1 - [Place of the marine eye, near Avenida da Boavista], undated [late 18th century]

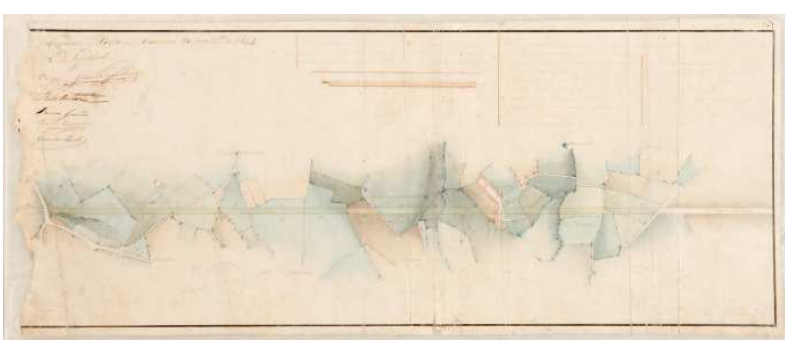

Figure 2 - [Plan for the continuation of Rua da Boavista from the point where it is taken, until crossing the Estrada de Matosinhos], 1854.

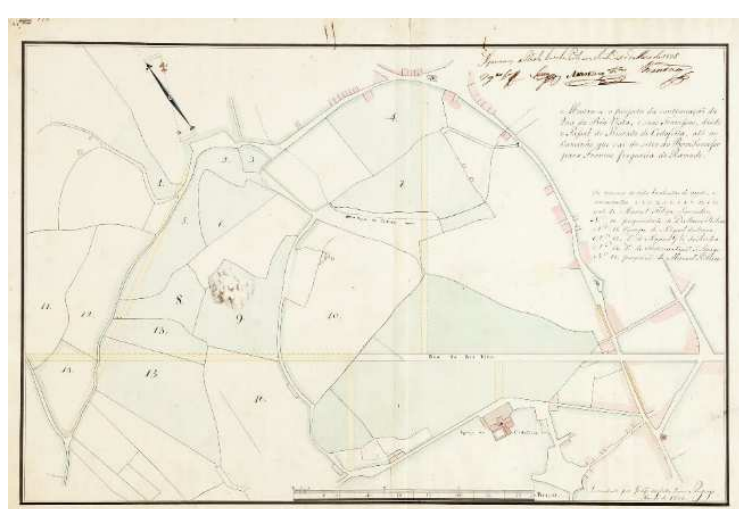

Figure 3 - "It is shown the project of the continuation of Rua da Bôa Vista, and its Crossings, from the Passal do Priorado of Cedofeita, to the Caminho that go from the site of Bom Successo to Francos of Ramade", 1825.

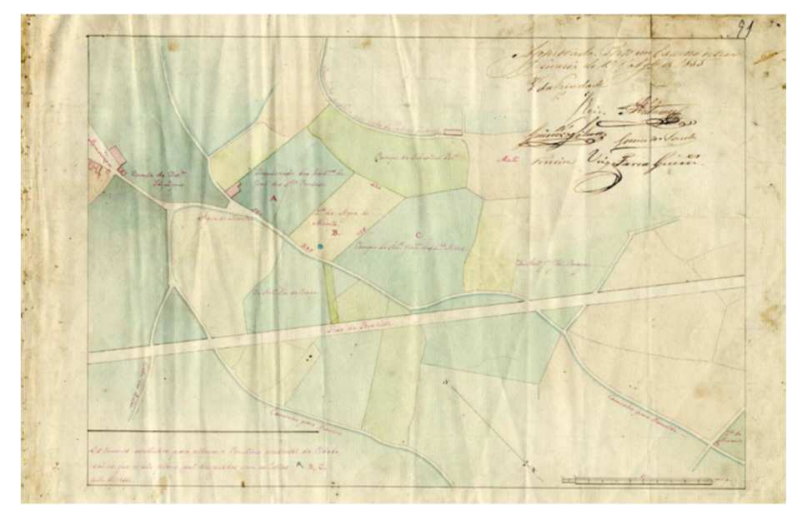

Figure 4 - "The lands chosen to place the western cemetery of the City are those that are assigned in this plan with the Letters A, B, C. July 1855"

Thus, it is understandable that the documents found mirror the rules outlined by Manoel de Azevedo Fortes, emphasizing the intention of imitation of nature as a fundamental principle in Cartography, using color according to their most common and direct readings, suggesting the use of the colors close to those represented by the actual exhibition, identifying the "carmine" or "vermilion" for the roofs of the buildings; the "verdigree liquid", which "to be good must draw the azure blue", to the watering of rivers; the "beech green" or the "lilygreen" for the vegetable gardens and gardens, etc. These are the rules that conditioned and help to explain images such as the following. However, in addition to the way symbols are used, the 
characteristics of the elements of the map also make it possible to anchor these documents in the rules of Azevedo Fortes, in defense of an objective and precise plant model, namely by standardizing the composition elements, adding to the uniformity of the scales the simplification and standardization of the beams, captions or position of the rose-winds (or the north-pointing arrow), all verifiable in the above-mentioned figures of Boavista.

Throughout the nineteenth century, particularly in the second half with the incremente of public works, there was a significant increase in the number of "building conductors", which allowed some diversity in their formation and led to a certain pragmatism in the design of cartographic documents, increasingly seen as simplifying tools to express the work to be accomplished. In this context, documents have begun to appear more more simple, keeping the essential of the previous rules, but focusing on the project of the "work" (road, street) to be carried out, regardless of elements such as the water color of the fields or conditioners "borders", taking advantage of any space left to place notes and observations, references to municipal deliberations or dates and signatures of municipal officials.We are in a pragmatic and expeditious phase in which the plant or project, as a designed instrument, when losing some of the care and normalization which it had previously with Azevedo Fortes, is diminished as a document, which can be verified in the examples of this typology presented below.

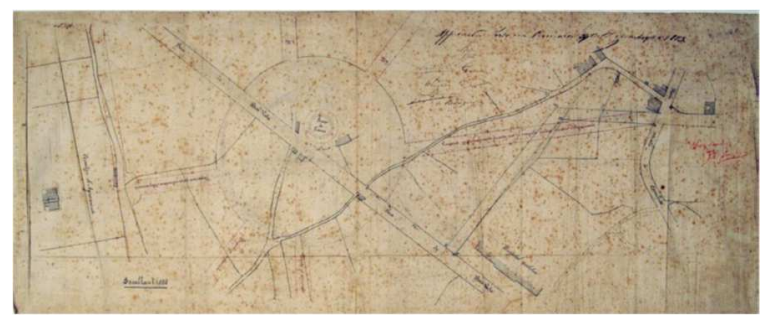

Figure 5 - [New street for the cemetery of Agramonte and the prolongation of the new street already torn for the cemetery of Agramonte], 1873.

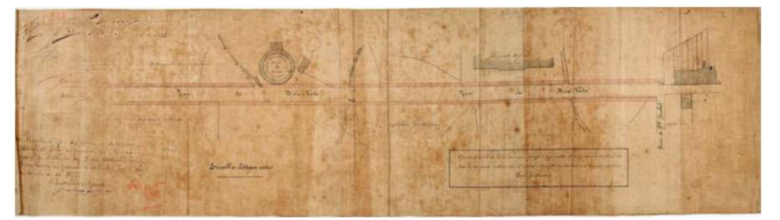

Figure 6 - "Plan referred to in the resolution of the Cam. do Porto, approved by agreement of District Council of 5 of the current month. Secretariat of the Civil Government of the Port of May 1875"

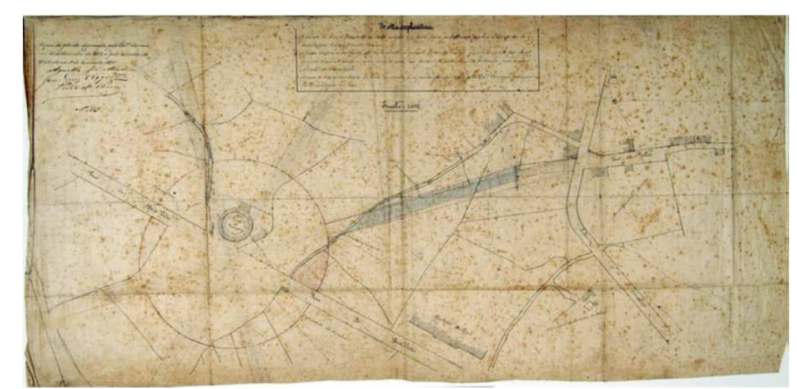

Figure 7 - "Copy of the plan approved by Ex Camara on December 29, 1873 and by the District Council on January 8, 1874".

Naturally, when it came to large-scale cartography, such as the comprehensive survey of the city in strict and detailed representation, in order to serve as a basis for urban intervention, but also as a noble and qualified document of urban representation, the agents were weighted, the care of them was accurate and the result was excellent, as was the case of the "Topographic Chart of the City of Oporto", with the scale of 1: 500, completed in 1892 under the direction of the military engineer Augusto Gerardo Telles Ferreira, that we analyze at another opportunity (Mário G. FERNANDES, 2011) and which continues to constitute an essential document for the morphogenesis of any part of the municipality of Porto. However, due to the practical necessity arising from the bureaucratization of the municipal works processes in the twentieth century, during the first republic and beyond, we see a new effort to standardize the image of projects for public works, which, although they remain manuscripts, the map elements (title, scale, author, legend, signatures, dates, etc.) in an area separate from the representation, organized on a "front page", normally left side of the document. Examples of this type of document are presented below.

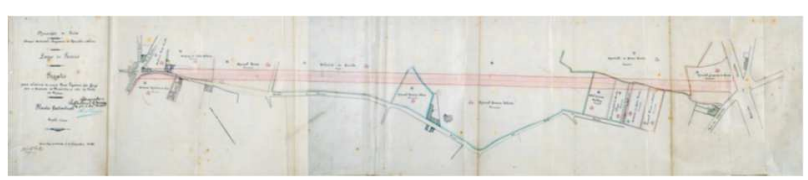

Figure 8 - "Largo de Pereiró. Project to open a street linking this Largo and Avenida da Boavista on the site of Fonte da Moura. Cadastral Plan", 1915.

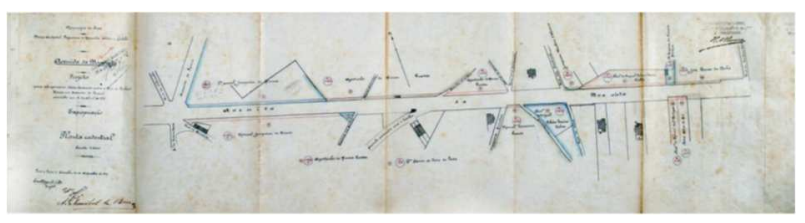

Figura 9 - "Avenida da Boavista. Project to enlarge this Avenue between Rua do Pinheiro Manso and Avenida de Pereiró approved on April 15, 1875. Expropriation. Cadastral plant.", 1917. 


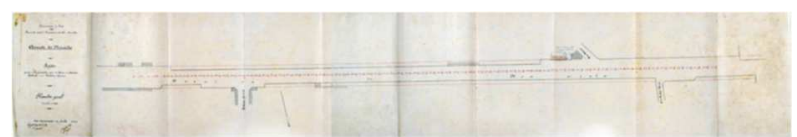

Figura 10 - "Avenida da Boavista. Project for enlargement between the streets of Azevedo Coutinho and Pinheiro Manso. General plant", 1917.

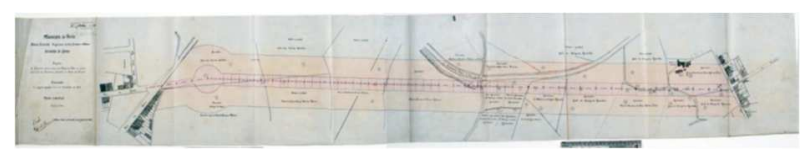

Figura 11 - "Avenida do Gama. Project of Avenue between the rua da Cerca, in the Foz and the present Avenida da Boavista, near Fonte da Moura. Variant to the project approved on November 7, 1914. Cadastral Plan.", 1920.

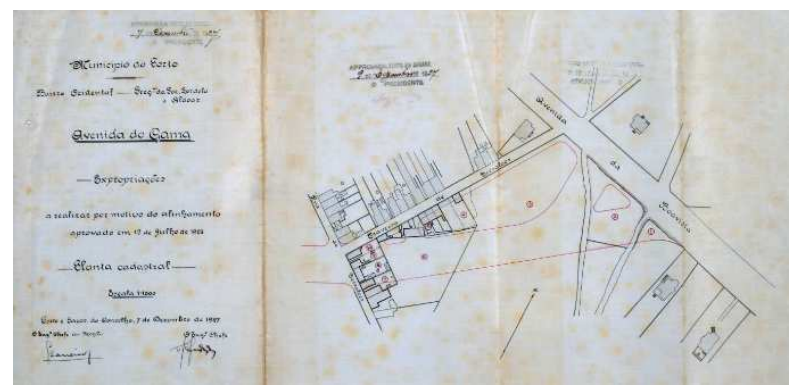

Figura 12 - "Avenida do Gama. Expropriations to be carried out due to the alignment approved on July 17, 1923. Cadastral Plan", 1927.

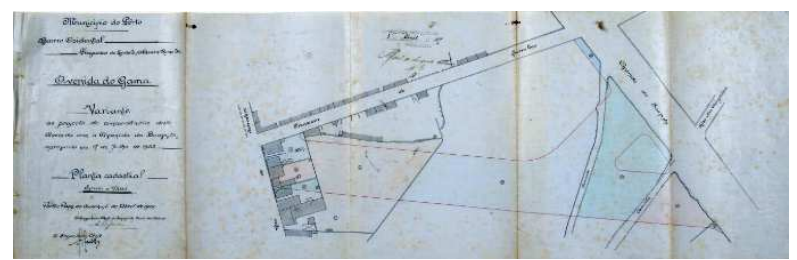

Figura 13 - "Avenida do Gama. Variant to the project of agreement of this Avenue with the Avenida da Boavista, approved on July 17, 1923. Cadastral Plan.", 1929.

Finally, in the Estado Novo (1933-1974), there was a new transformation of the image of urban projects. Firstly, because the crucial political decision of Eng. Duarte Pacheco to begin the systematization of urban cartography and urban planning in Portugal, providing the municipal councils with the cartographic instruments necessary for the elaboration of urbanization plans and led, between 1938 and 1942, to the production and profusion of basic urban cartography, of large scale $(1: 1.000$ or $1: 2.000)$ and encompassing all the urban clusters, carried out by the Sociedade Portuguesa de Levantamentos Aéreos, Lda., with the use of photogrammetry and new printing and reproduction techniques, facilitated the delineation of a standardized graphic image with particular aesthetic characteristics that were adapted to a strong and refined image, consciously sought for the propaganda of the regime. It exemplifies it, as far as the study of the morphogenesis of Avenida da Boavista is concerned, the "Arrangement of the concordance of Avenida Antunes Guimarães with Rua da Vilarinha and with Avenida da Boavista (variant with the study of the implantation of the buildings to be built), 1960, where, in addition to the slight use of the visual value variable, we can observe the maintenance of the delimitation of a rectangular area in which the elements of the map, now placed in the lower right corner, are organized, as is still generally the case today.

As in other cases, the study of the Boavista axis has allowed, through the analysis of the old cartography, to identify and understand each of the moments of the respective structuring, both by the intrinsic characteristics of the various cartographic documents, per se and by the consideration of the mutual conjugation, either by identifying the morphological content that contributed to the morphogenetic analysis and refers us to the intervention proposal and its roots.

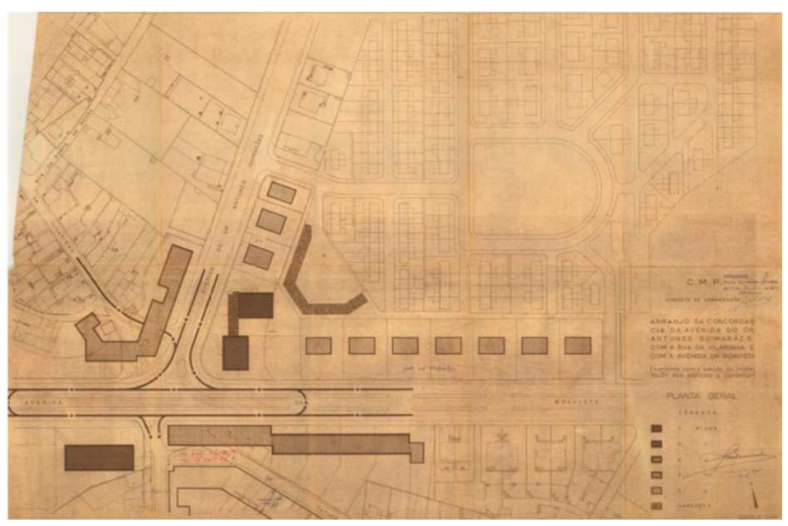

Figura 14 - "Arrangement of Avenida Dr. Antunes Guimarães Avenue with Rua da Vilarinha and with Avenida da Boavista (variant with the study of the implantation of the buildings to be built). General plant", 1960.

\section{The proposed intervention}

The Avenida da Boavista has three sectors, and sectors $\mathrm{A}$ and $\mathrm{C}$ (from the east and west, respectively) were previously involved in the correspondence to projects with different options regarding the organization and qualification of their profiles.

Now, the central sector B (between the Burgo building/Granja river and the City Park/Aldoar river) is responsible for the recomposition of unit standards, in addition to highlighting the various particular circumstances.

The intention was to find a "good idea" of urban structure and environmental valorization to complete the process of requalification of Boavista avenue, which integrates interventions already performed in a space, 
functional, environmental and significant system, aiming at a coherent whole, easily recognizable, properly developed, articulated and hierarchical. In this sense, the entire axis and its neighboring areas of influence were considered as a totality for which adequate treatment becomes indispensable the need to recognize and frame reasons of interest, values and dissonances, dynamics, problems and transformational potentialities that allow outline a strategic perspective for designing future intervention. the exercise of the urban performance on the space of the existing city. In essence, it was a question of detecting a set of possible disciplinary invariants of a morphological nature related to the layout and the splitting, or the relations with the building, perceiving the reasons of its genesis and its evolutionary processes.

Such testimonies carry the memory of the intervened places, facilitating their evocation, by the narrative of the urban project, as tools of interpretation of the signs of identity to operate. As carriers of the memory of

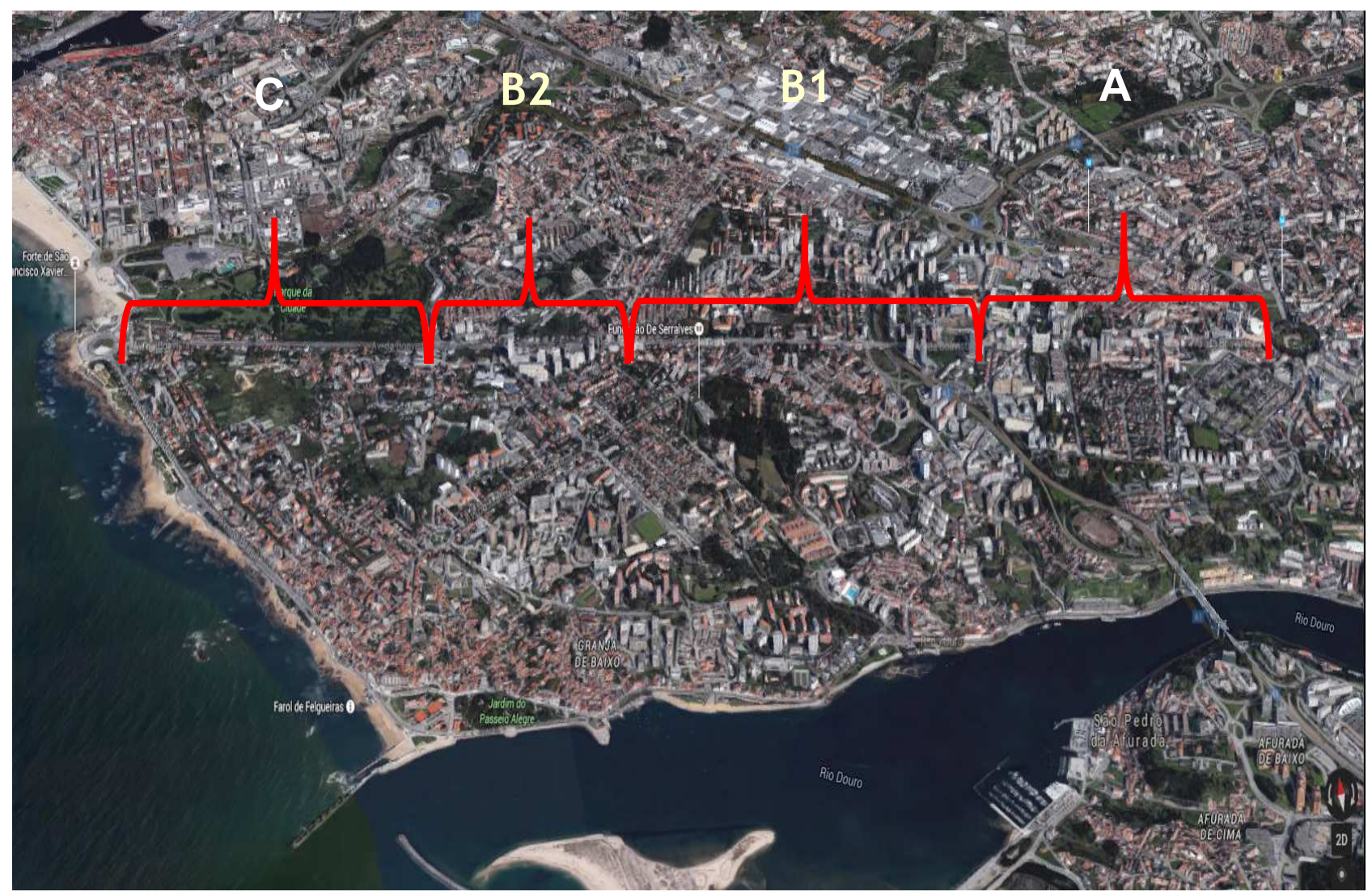

Figura 15 - Identification of sectors (A, B and C) of Avenida da Boavista.

Methodologically, among other tasks, several old cartographic documents were analyzed, corresponding to the whole axis and the surrounding areas, looking for the reasons of the corresponding forms of urban growth and consolidation. It was intended to find in the historical cartography and in the projects of the city, some of the rules applied in the past that could inform morphological and cultural values, establishing a hierarchy of values that characterize the relations between the spatial and social, can be re-mapped by the urban design, being essential the identification of the characteristics of the traces, alignments and profiles, isolated elements and structures such as walls, buildings, tanks and water lines, among other facts mapped and

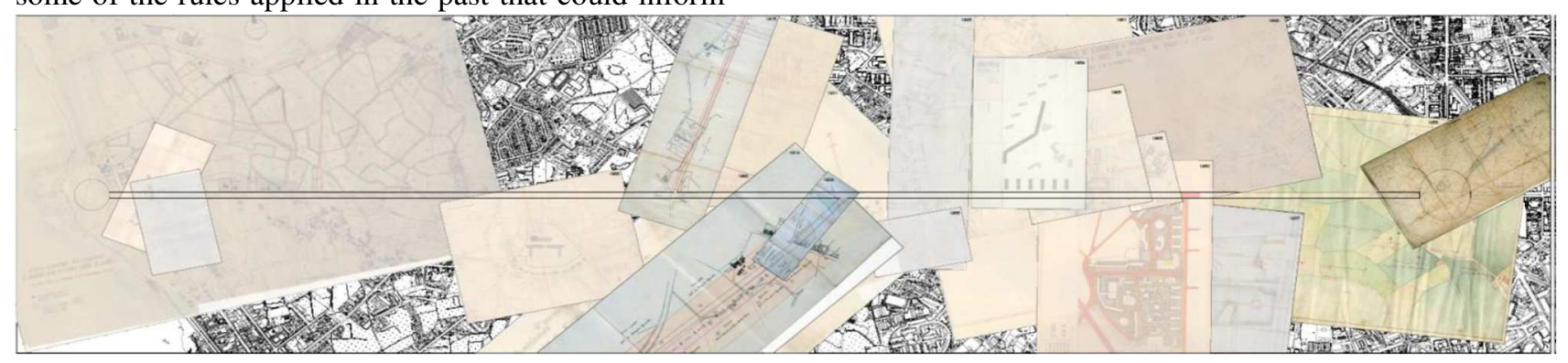

Figura 16 - First Projects for the morphogenesis of the adjacencies to Boavista Avenue 
readable in the old cartography. In addition to the importance of the casuistry, from the cartography documents have been produced that are both process and product and contribute to express an image from the preexisting forms, adding new readings of the territory, namely the figure on the "First projects for the morphogenesis of the adjacencies to the Avenida da Boavista", as well as the map derived from the "Morphogenetic references of the Boavista axis". operationalizing contributions of the project, with the following following essential points:

- area "between streams", to emphasize and consider as potential generators of landmarks in the landscape, even if presently they are "hidden";

- the Ribeira de Aldoar, partly piped and lateralized along Avenida da Boavista, before diverge to the City Park, presenting itself as a central element in defining the profile of Avenida da Boavista; its disengage and urban insertion, on the open air, is one of the innovative

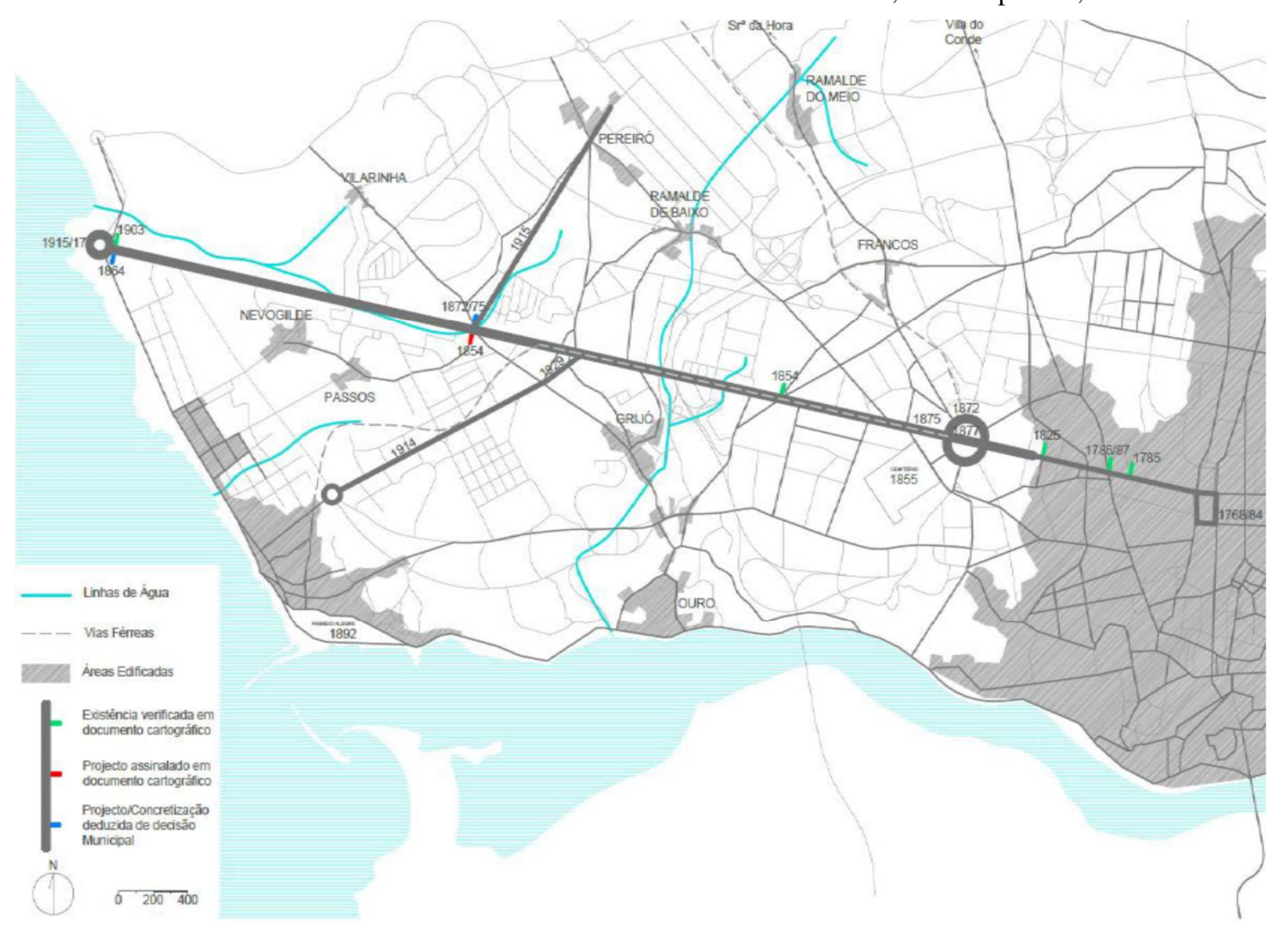

Figura 17 - Mornhogenetic references of Boavista axis

In an approximation to the subject area of the study, it was found, for example, that the structuring of intervention on Avenida da Boavista in three sectors (A, $\mathrm{B}$ and $\mathrm{C}$ ) was in line with its own openness over time, in three stages and explained by the existence of two difficulties, in advance of which there was an element of the urban fabric that allowed adequate provisional finishing: the first one constituted by the water lines and loams generated by the "Olho Marinho" and the Ribeira da Granja, whith the punch line allowed by Rua Tenente Valadim; the second centered on the Aldoar stream, serving as a provisional link to Rua da Vilarinha. The different times / moments and the different relative positions would conform the morphological diversity of the three sections of the avenue.

Based on the morphogenetic recognition of the intervention area, characteristics considered important were highlighted as potentially generating and aspects of the program; the emergence and disappearance of water are events organized by traditional pattern structures (tank), alluding to similar artifacts identified in the historical cartography analyzed;

- the Ribeira da Granja, the most significant water course in the interior of the municipality of Porto, which maintains environmental and urban leisure potential, reinforced with water lines originating in the "Marine Eye", registered since the 18th century and conditioner, still today, of the occupation of the nearest land;

- the genesis of the Boavista axis (between 1784 and 1915/17) was more complex than its current layout appears; (5 fathoms, about 11 meters) suitable for the function and at the time when it began to be delineated (1784-1825), was designed as a radial route, starting in 1854 , when it was perceived as avenue, initially with a profile still contained ( 8 fathoms, about 18 meters) and soon rethought, in the 1870 s, in a contemporary strategic vision that could be verified in the creation of the 
roundabout and in the extension of the profile to 26 meters, which made it a "kind of guideline of the Portuguese urbanization, an authentic backbone of the organization of the western space of the city" (OLIVEIRA, J. M. P., 2007, 1st edition 1973, p. 331). Today, maintaining significant variations in its transversal profile, its rectilinearity is clearer in the cartographic documents than in the urban landscape, which suggests the need to treat and reinforce its image; - the heterogeneity of the whole sector B implies the need to find a defining element / marker of a strong image of continuity that can be based on the afforestation in alignment, with study of rhythms and sequences aiming at the deepening of an urban qualified image;

- the existence of a pattern of the fronts of the allotment structure, accurately identified by the topographical map and interpreted in historical cartography as a persistent measure for built-up uses corresponding to several typological senses, allows to constitute a longitudinal cadence with 14 meters as the basis of the work stereotomy of the project, marking all the aspects of the geometry of the public space, allowing the resolution of intersection and gradient concordances in presence and being favorable to the desired flexibility conditions.

Naturally, the high performance of urban networks and infrastructures, the elevation of the conditions of qualification and comfort of the public space, the rehabilitation of environmental factors (existing and latent) and their articulation in relevant experiential systems, are presented, among others, as some of the motivations and generators of the urban action that is intended to be innovative, distinctive and diffuse of cultural meanings inherent to the identity and character of the intervened places, to the city and its users. The replacement of a central platform, the widening of sidewalks and the expressive forestation with four alignments of alvarinho oak are the main characteristics of the recommended solution, whose geometry presents a reserve of flexibility in order to allow different regimes of use over time. It is mainly the treatment of the central path that can be used for pedestrians and bicycle lane, the collective transportation route (BUS or light rail) or the urban insertion of the Aldoar stream, whose uncover is intended by the City Hall. Moreover, the aforementioned central strip strongly influenced the historic profile of the avenue, where the railway platform was inserted, of which vestiges still exist today. The expressive environmental qualification is based on the theme of water that, together with the intense afforestation and the generous profiles of the pedestrian surfaces, intends to reinforce the urban ecological structure, with pedestrian and cycle paths connecting the Atlantic front and Park of the City to the river Aldoar and ribeira da Granja, along which you can access other park areas (Serralves and Pasteleira) and the Douro riverfront. In essence, the project aims to improve the conditions of accessibility, comfort and environmental qualification of the public space, privileging its pedestrian use, enabling it for smooth mobility modes, without harming the attributed competences as a structuring and intermunicipal linkage distributor. It is intended to ensure a level of road service appropriate to the system in which the avenue is inserted, but compatible with a relevant urban and environmental qualification and consonant with the quality of life expectations of the users of the contemporary city. The challenge of reconciling functional and environmental interests in a reduced space is based on the principles of flexibility that guide the design of the public space, allowing the assumption (and experimentation) of management methodologies of an equally flexible nature, thus ensuring better conditions for implementation and perenniality of the solutions recommended. In summary, the contextualization of urban planning considered contemporary solutions for the design of the public space, but recognized and gave importance to the history of the city and the places to be reclassified, historical cartography being one of the main sources of information, where significant values to be considered as project materials and interpreted the various processes of urban space production. 


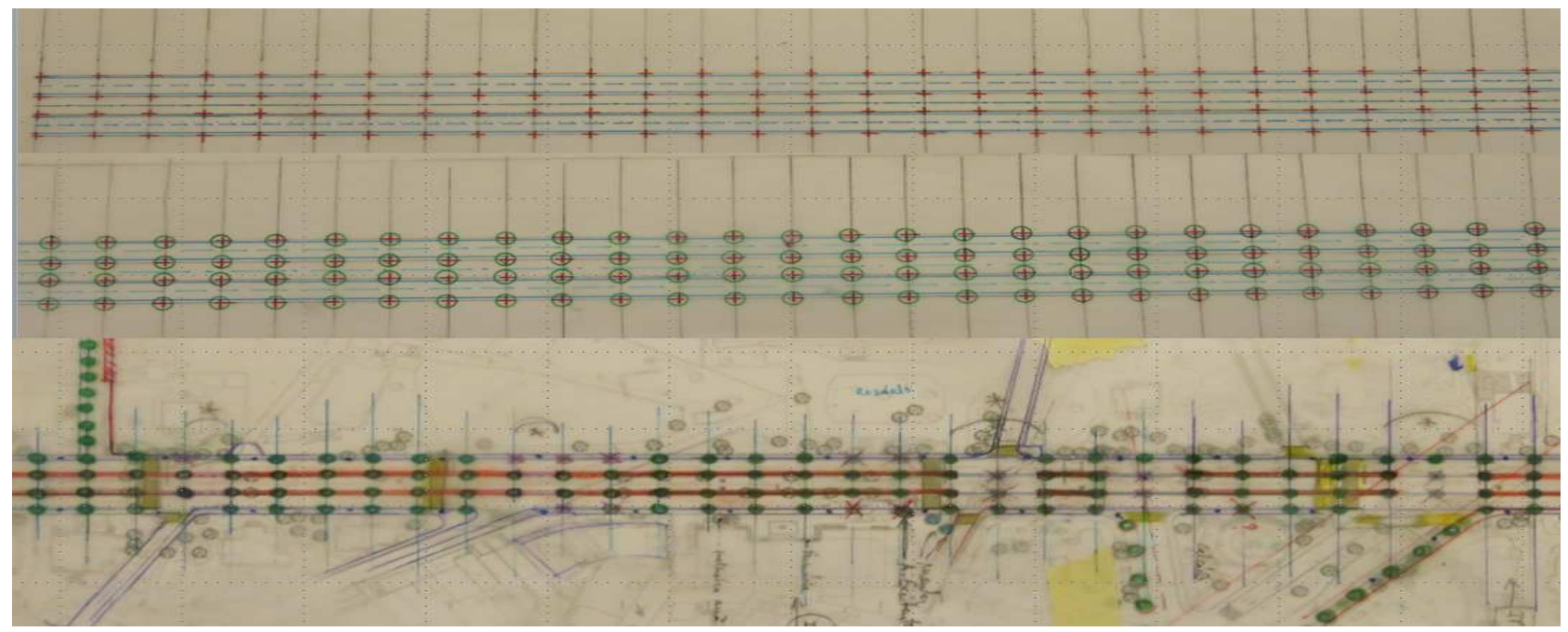

Figura 18 - Study of work stereotomy

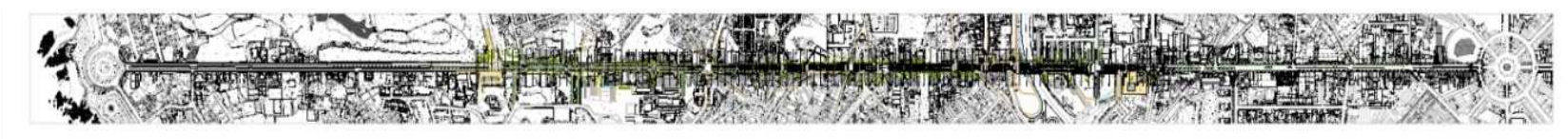

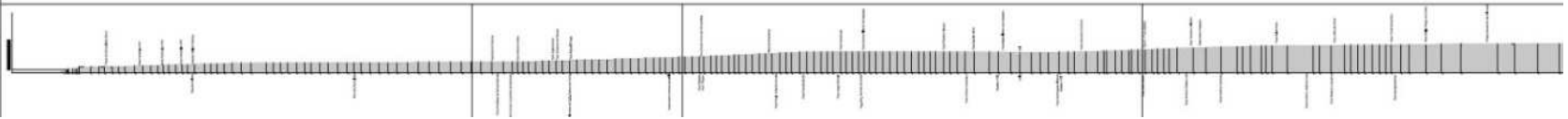

Figura 19 - Longitudinal profile of the Axis of the Boavista and Joint Plant, with demarcation of the Proposed Work Stereotomy and articulation between the sectors.
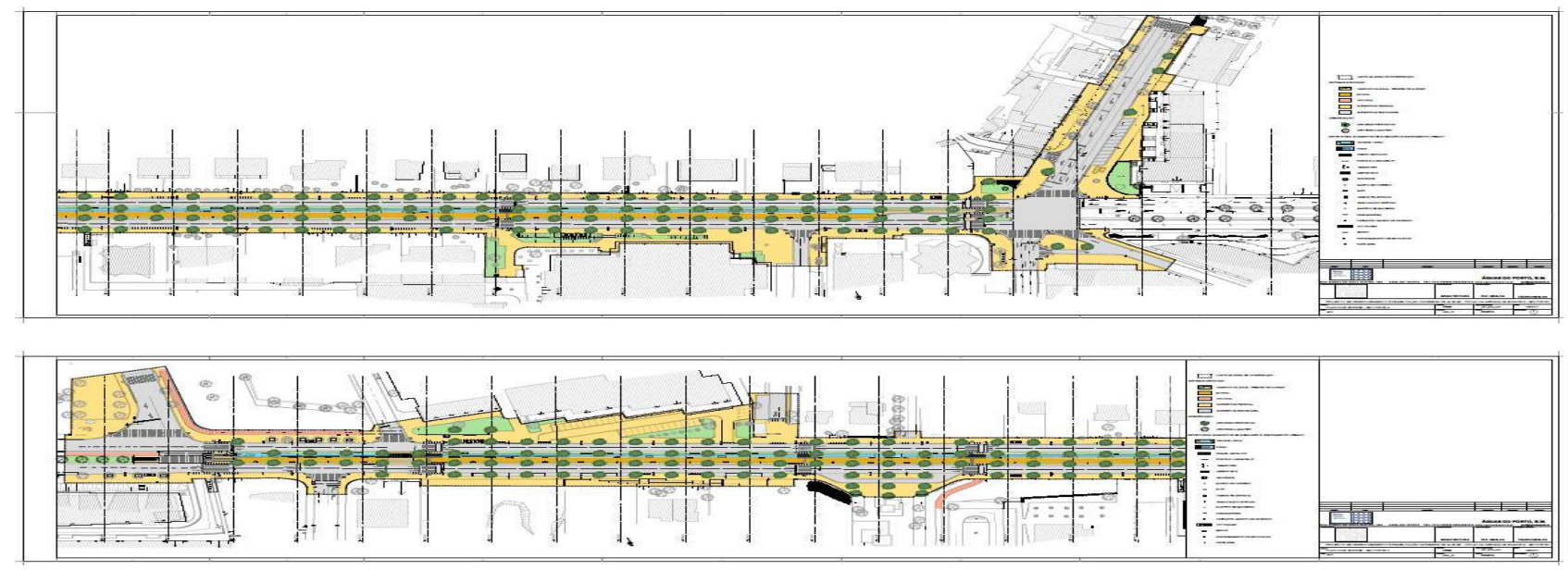

Figura 20 - General Project B2

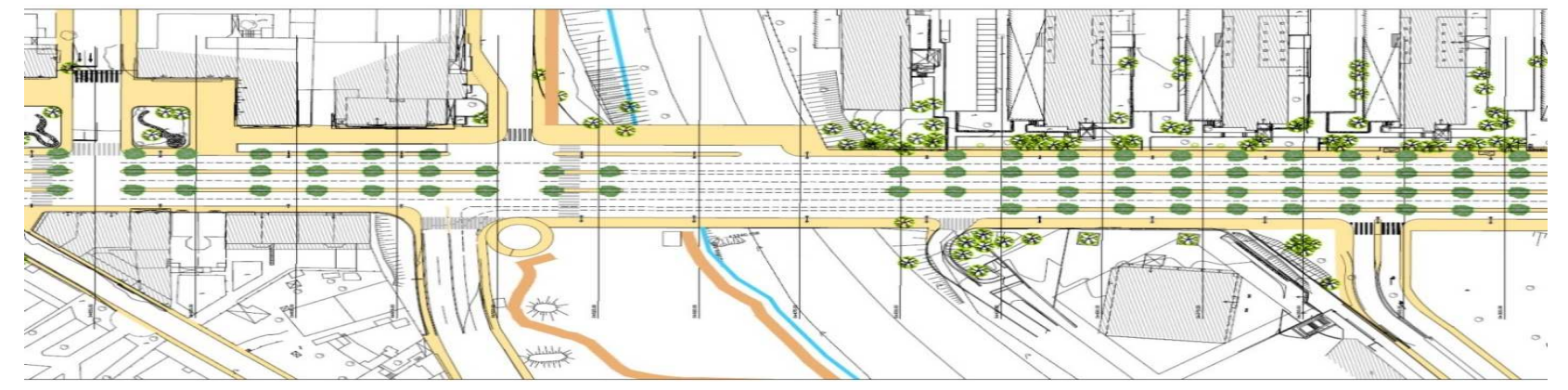

Figura 21 - Synthesis Plant - B1 segment on the Via de Cintura Interna 


\section{Documentos cartográficos referidos do Arquivo Histórico Municipal do Porto:}

[Lugar do olho marinho, na proximidade da Avenida da Boavista], sem data [finais do século XVIII] - [Place of the marine eye, near Avenida da Boavista], undated [late 18th century], Ludovicus Ignacius de Barros Lima fecit, 100 Braças (AHMP, cota: DCDT/A3-153).

[Plano para a continuação da Rua da Boavista desde o ponto a que se acha levada, até cruzar a Estrada de Matosinhos] - [Plan for the continuation of Rua da Boavista from the point where it is taken, until crossing the Estrada de Matosinhos]. Approvado. Porto em Camara, 30 de Março de 1854. Escala de 200 braças (AHMP, cota: D-CDT/A3-311).

"Mostra-se o projecto da continuação da Rua da Bôa Vista, e suas Travessas, desde o Passal do Priorado de Cedofeita, até ao Caminho que vae do sitio do Bom Successo para Francos freguesia de Ramade" - "It is shown the project of the continuation of Rua da Bôa Vista, and its Crossings, from the Passal do Priorado of Cedofeita, to the Caminho that go from the site of Bom Successo to Francos of Ramade", Levantado por Joaq.m da Costa Lima e Sampaio, Março de 1825. Aprovado em Junta, Maio de 1825. Escala de 150 braças (AHMP, cota: D-CDT/A3-140).

"Os terrenos escolhidos para collocar o cemitério occidental da Cidade, são os que neste plano são assignados com as Letras A, B, C. Julho de 1855 " - "The lands chosen to place the western cemetery of the City are those that are assigned in this plan with the Letters A, B, C. July 1855", Approvado. Porto em Camara em 1 de Agosto de 1855. 100 Braças (AHMP, cota: D-CDT/A3343).

[Nova rua para o cemitério d'Agramonte e Variante no prolongamento da nova rua já rasgada para o cemitério d'Agramonte] - [New street for the cemetery of Agramonte and the prolongation of the new street already torn for the cemetery of Agramonte], Approvado em camara em 26 de Dezembro de 1873, Escalla 1:1.000 (AHMP, cota: D-CMP-03-249).

"Planta a que se refere a deliberação da Cam. do Porto, aprovada por accordao do $\operatorname{Cons}^{\circ}$ de districto de 5 do corrente mez. Secretaria do Governo Civil do Porto de Maio de 1875" - "Plan referred to in the resolution of the Cam. do Porto, approved by agreement of District Council of 5 of the current month. Secretariat of the Civil Government of the Port of
May 1875", Escalla: 0,004 por metro, Approvado. Porto. Em Camara, 15 de Abril de 1875 (AHMP, cota: D-CMP-03-136-004 e 003).

“Cópia da planta aprovada pela Exma Camara em 29 de Dezembro de 1873 e pelo Conselho de Distrito em 8 de Janeiro de 1874" - "Copy of the plan approved by Ex $^{\text {a }}$ Camara on December 29, 1873 and by the District Council on January 8, 1874", 1:1.000 (AHMP, cota: D-TGa-CMP-02-343-002).

"Largo de Pereiró. Projecto para abertura de uma Rua ligando este Largo com a Avenida da Boavista no sitio da Fonte da Moura. Planta Cadastral" - "Largo de Pereiró. Project to open a street linking this Largo and Avenida da Boavista on the site of Fonte da Moura. Cadastral Plan". 1:1.000. Porto e Paços do Concelho, 13 de Dezembro de 1915 (AHMP, cota: D-CMP-20-048-005).

"Avenida da Boavista. Projecto para o alargamento entre as ruas de Azevedo Coutinho e do Pinheiro Manso. Planta geral" - "Avenida da Boavista. Project for enlargement between the streets of Azevedo Coutinho and Pinheiro Manso. General plant". Escala 1:500. Porto e Paços do Concelho, 24 de Julho de 1917 (AHMP, cota: D-CMP-03-136-006).

"Avenida da Boavista. Projecto de alargamento d'esta Avenida entre a Rua do Pinheiro Manso e a Avenida de Pereiró aprovado em 15 de Abril de 1875. Expropriação. Planta cadastral." - "Avenida da Boavista. Project to enlarge this Avenue between Rua do Pinheiro Manso and Avenida de Pereiró approved on April 15, 1875. Expropriation. Cadastral plant." Escala 1:1.000. Porto e Paços do Concelho, 29 de Setembro de 1917 (AHMP, cota: DCMP-20-064-007).

"Avenida do Gama. Projecto de Avenida entre a rua da Cerca, na Foz e a atual Avenida da Boavista, próximo a Fonte da Moura. Variante ao projecto aprovado em 7 de Novembro de 1914. Planta Cadastral." - "Avenida do Gama. Project of Avenue between the rua da Cerca, in the Foz and the present Avenida da Boavista, near Fonte da Moura. Variant to the project approved on November 7, 1914. Cadastral Plan." Escala 1:1.000. Porto e Paços do Concelho, 5 de Julho de 1920 (AHMP, cota: DCMP-03-230-004).

"Avenida do Gama. Expropriações a realizar por motivo do alinhamento aprovado em 17 de Julho de 1923. Planta Cadastral" - "Avenida do Gama. Expropriations to be carried out due to the alignment approved on July 17, 1923. Cadastral Plan". Escala 1:1.000. Porto e Paços do Concelho, 7 de Dezembro de 1927 (AHMP, cota: D-CMP-20-128-004).

"Avenida do Gama. Variante ao projecto de concordância desta Avenida com a Avenida da Boavista, aprovado em 17 de Julho de 1923. Planta Cadastral." - "Avenida do Gama. Variant to the project of agreement of this Avenue with the 
Avenida da Boavista, approved on July 17, 1923. Cadastral Plan." Escala 1:500. Porto e Paços do Concelho, 2 de Abril de 1929 (AHMP, cota: DCMP-20-128-007).

"Arranjo da concordancia da Avenida Dr. Antunes Guimarães com a Rua da Vilarinha e com a Avenida da Boavista (variante com o estudo da implantação dos edifícios a construir). Planta Geral" "Arrangement of Avenida Dr. Antunes Guimarães Avenue with Rua da Vilarinha and with Avenida da Boavista (variant with the study of the implantation of the buildings to be built). General plant", 1960. Escala 1:200 (AHMP, cota: D-CMP/4 (159)). urban space of Porto. Natural conditions and development]. Porto, Edições Afrontamento.

MEALHA, Rui P. (coord.), FERNANDES, Mário G., MEALHA, Tádzio, MAGALHÃES, Daniel (2017), Estudo Prévio para o Desentubamento e Reabilitação da Ribeira de Aldoar. Troço da Avenida da Boavista. Estudo de Enquadramento e Programa Base [Preliminary Study for the uncover and rehabilitation of Ribeira de Aldoar. Section of Boavista Avenue. Framework Study and Base Program]. Porto, Câmara Municipal do Porto (policopiado).

\section{Referências bibliográficas referidas:}

FERNANDES, Mário G. (2011), "Plantas do planeamento urbano e do urbanismo em Portugal (1864-1926)" ["Plans of urban planning and urbanism in Portugal (18641926)"], Atas do IV Simpósio Luso-Brasileiro de Cartografia Histórica, Porto, FLUP (http://eventos.letras.up.pt/ivslbch/comunicaco es/114.pdf).

FERNANDES, Mário G. (coord.) (2006), Manuel de Azevedo Fortes (1660-1749): Cartografia, Cultura e Urbanismo [Manuel de Azevedo Fortes (1660-1749): Cartography, Culture and Urbanism], Porto, GEDES e Departamento de Geografia da Faculdade de Letras da Universidade do Porto.

FORTES, Manuel de Azevedo, $O$ Engenheiro Portuguez. Lisboa, Officina de Manoel Fernandes da Costa, Impressor do Santo Officio, 1728: Tomo Primeiro; 1729: Tomo Segundo.

FORTES, Manuel de Azevedo (1722), Tratado do Modo o mais facil e o mais exacto de fazer as Cartas Geograficas, assim da Terra como do Mar, e tirar as plantas das Praças, cidades, $e$ edificios com instrumentos e sem instrumentos (...), Lisboa, Offic. de Joze Antonio Plates.

HENRIQUES, Helena Cristina Neto (2012), Análise morfológica de alguns espaços públicos: Cidade do Porto $1910 \quad-1974$ [Morphological analysis of some public spaces: Town of Porto 1910 -1974]. Porto, FAUP (Dissertação de Mestrado, policopiado).

OLIVEIRA, José Manuel Pereira de $\left(2007,1^{\text {a }}\right.$ edição 1973), O espaço urbano do Porto. Condições naturais e desenvolvimento [The 